\section{International Field Workshop on the Marwar Supergroup, Rajasthan, India}

\author{
20-28 January 2014, Rajasthan, India
}
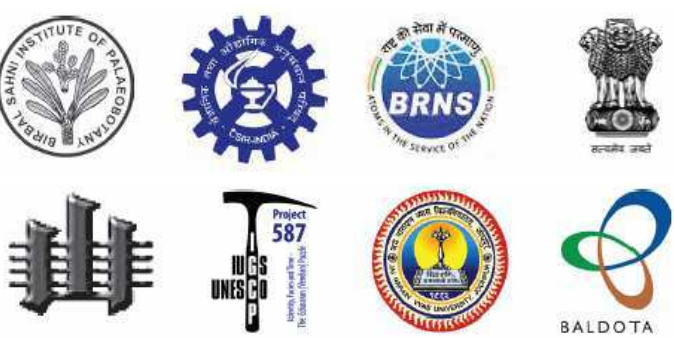

The Marwar Basin in western Rajasthan is one among the many Proterozoic sedimentary basins developed in Peninsular India that preserve rich records of the geological history and is traditionally considered as Trans-Vindhyan basin developed across Delhi and Aravalli orogens. It contains sedimentary package classified under Marwar Supergroup thought to be equivalent to the Vindhyan Supergroup. However, recently acquired radiometric dates suggest that the Marwar Supergroup is distinctively younger than the Vindhyan Supergroup, and the two basins were independently developed although they shared some of their provenance regions (Malone et al., 2008; McKenzie et al., 2011; Davis et al., 2014; Turner et al., 2014). This realization plus many recent paleontological discoveries from the Vindhyan and Marwar supergroups (Kumar et al., 2009; Prasad et al., 2010; Kumar and Ahmad, 2012; Kumar et al., 2012; Srivastava, 2012; Pandey et al., 2014; Srivastava, 2014; Davis et al., 2014) necessitated an in depth on-field discussions on these two basins. The first field workshop on the Vindhyan Supergroup was organized during the year 2010 (Kumar and Sharma, 2012) and the next on the Marwar Supergroup was conducted during January 20-28, 2014 (Sharma et al., 2014). Besides the interest of academia, there is an increasing interest of the petroleum industry in the hydrocarbon potential of this region (Ghori et al., 2009; Craig et al., 2013)().

The field workshop on Marwar Supergroup drew 34 participants from Argentina, China, Germany, India, Oman, Spain, United Kingdom, and United States. The programme started with a symposium (January 20,2014) at the Department of Geology, Jai Narayan Vyas University in Jodhpur, Rajasthan, with several talks covering the regional geology, stratigraphy, palaeogeography, geochronology, and chemostratigraphy of the Marwar Supergroup and equivalent successions. This symposium provided an excellent primer for the ensuing outcrop discussion. It was very clear from the very beginning of the workshop that geochronological constraints, detailed sedimentological and stratigraphic data, and careful palaeontological analysis would be the focal points of field discussion.

The field work near Jodhpur (January 2123), focussed on (i) the contact between the Marwar Supergroup and the underlying 770 Ma Malani Igneous Suite; (ii) sedimentary structures in the Sonia Sandstone of the Jodhpur Group; (iii) macroscopic fossils in the Sonia Sandstone; (iv) bituminous limestone of the Gotan Formation and (v) the contact between the Pondlo Dolostone and the overlying Nagaur Group. The suite of sedimentary structures in the Sonia Sandstone beneath the magnificent Mehrangarh Fort incited intensive discussion on the sedimentary environments of the lower Jodhpur Group. There seems to be evidence suggesting that the lower Jodhpur Group, particularly the Pokaran Conglomerate and perhaps the lower Sonia Sandstone were deposited in fluvial systems, and much of the remaining Sonia Sandstone was deposited in foreshore and shoreface environments. The Sonia Sandstone preserves abundant microbially induced sedimentary structures and numerous enigmatic structures that have been interpreted as discoidal fossils and megaplant fossils; if correct, these could potentially offer new insights into the Neoproterozoic evolution of macroscopic life.

On January 24, the group examined a pink limestone at the Gotan Limestone - Pondlo Dolostone transition and a section of a pyroclastic bed at the Sonia Sandstone Girbhakar Sandstone transition in the Jodhpur Group, near Nagaur. There was extensive discussion at the outcrop on the origin and potential implications of this pyroclastic bed. This pyroclastic bed could be dated and may provide a much needed age constraint on the depositional age of the Jodhpur Group. Several samples were taken for radiometric dating and palaeomagnetic analysis.

On the following day, the group examined abundant trace fossils preserved in the Nagaur Sandstone near Dulmeraincluding Rusophycus, Cruziana, Monomorphichnus,
Isopodichnus, Treptichnuspedum, Bergaueria, among many othersthat suggest the Nagaur Sandstone to be no older than the lower Cambrian (Stage 2 of Terreneuvian). This is consistent with the youngest zircon (ca. $536 \mathrm{Ma}$ ) extracted from the Nagaur Sandstone as reported in previous studies (Malone et al., 2008; McKenzie et al., 2011; Turner et al., 2014). There was much discussion on the outcrop about the sedimentary environments of the Nagaur Sandstone and the need to carry out a careful analysis of the environmental distribution of trace fossils.

On January 26, the group moved camp to Sam west of Jaisalmer, stopping near Pokaran to examine the Pokaran Conglomerate at the base of the Jodhpur Group. The Pokaran Conglomerate has been variously interpreted as fluvial or glacial deposits. The participants discussed these alternative interpretations and concluded on the basis of sedimentary structures and stratigraphic relationships that the Pokaran Conglomerate is likely fluvial deposits.

On the return trip back to Jodhpur on the last day of field excursion, the group visited the beautiful PatwaHaweli in the Golden City Jaisalmer and examined additional outcrops of the Malani Igneous Suite and the Sonia Sandstone. The PatwaHaweli gave the participants an opportunity to appreciate the rich historical and architectural heritage of Rajasthan. Upon return to Jodhpur, the group had a valedictory function where scientific problems of the Marwar Supergroup were also discussed. Most participants felt that there is an imperative need to further constrain the depositional age of the Marwar Supergroup. At the present, the Marwar Supergroup is loosely constrained by the $\sim 770$ Ma Malani Igneous Suite and lower Cambrian trace fossils in the Nagaur Sandstone. The pyroclastic bed at the transition between the Sonia Sandstone and the Girbhakar Sandstone could potentially provide a much needed age constraint, and carbon and strontium isotope analysis of the Bilara Group could facilitate a chemo-stratigraphic correlation with other dated Neoproterozoic successions. It has also 


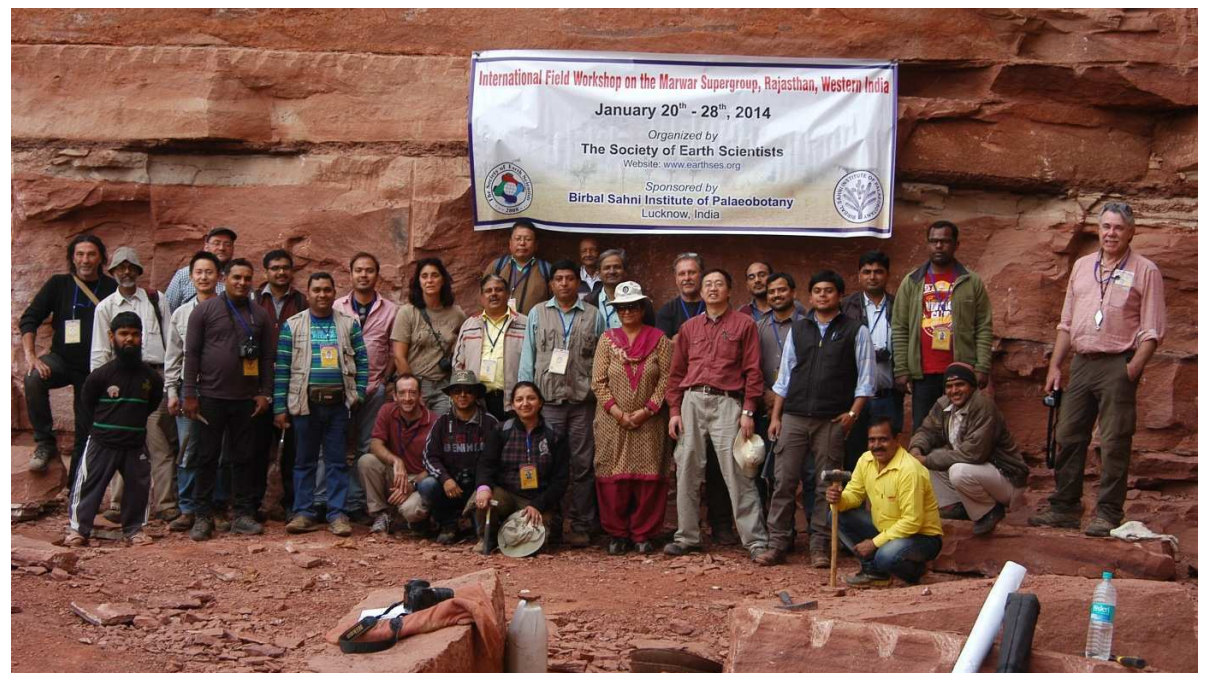

Group picture at a Dulmera quarry in front of the Nagaur Sandstone. From left to right: Daniel G. Poire, DilipSaha, quarry owner, Zhenbing She, Ulf Linnemann, UdayBhan, Bivin George, Veeru Kant Singh, Jamie Stewart, Irene Gomez, PranjalSaikia, Satish C. Tripathi, Ramson Asher, Bandana Dimri, Mukund Sharma, Surendra Kumar,Anand P. Singh, RajniTewari, Joseph G Meert, Shuhai Xiao, Arjun Singh Rathor, PitambarPati, Shamim Ahmad, BalramBhadu, Rajesh Awasthi (Assistant), Arif H. Ansari, Madan Kumar (Driver), Stuart D. Burley (photograph by Santosh Kumar Pandey).

been suggested that xenotime overgrowth could provide potential age constraints on the Jodhpur Group. One of the challenges in the study of Marwar Supergroup is the poor exposure of the stratigraphic succession. The scientific community should work closely with the petroleum industry that have drilled in the Marwar Basin.

The delegates appreciated the excellent field workshop and complemented Mukund Sharma and his team (Santosh K. Pandey, V. K. Singh, Arif Husain Ansari, A. S. Rathore, Shamim Ahmed,and Bandana Dimri) for the outstanding job done. The field workshop was organized by the Society of Earth Scientists (Lucknow) and supported by the Birbal Sahni Institute of Palaeobotany, Indian Council of Scientific and Industrial Research, Department of Atomic Research, New Delhi, International Subcommission on Ediacaran Stratigraphy, International Subcommission on Cambrian Stratigraphy, IGCP 587, the Jai Narayan Vyas University (Jodhpur), and Ramgad Minerals \& Mining Ltd (Hospet).

\section{Shuhai Xiao}

Department of Geosciences,

Virginia Polytechnic and State

University, Blacksburg, VA 24061, USA

\section{Mukund Sharma}

Birbal Sahni Institute of Palaeobotany, 53 University Road, Lucknow 226007, India

\section{References}

Craig, J., Biffi, U., Galimberti, R.F., Ghori, K.A.R., Gorter, J.D., Hakhoo, N., Le Heron, D.P., Thurow, J., and Vecoli, M., 2013, The palaeobiology and geochemistry of Precambrian hydrocarbon source rocks: Marine and Petroleum Geology, v. 40, p. 1-47.

Davis, J.K., Meert, J.G., and Pandit, M.K., 2014, Paleomagnetic analysis of the Marwar Supergroup, Rajasthan, India and proposed interbasinal correlations: Journal of Asian Earth Sciences, DOI:10.1016/j.jseaes.2013.09.027.

Ghori, K.A.R., Craig, J., Thusu, B., Lüning, S., and Geiger, M., 2009, Global Infracambrian petroleum systems: a review, in Craig, J., Thurow, J., Thusu, B., Whitham, A., and Abutarruma, Y., eds., Global Neoproterozoic Petroleum Systems: The Emerging Potential in North Africa: London, Geological Society Special Publications 326, p. 109-136.

Kumar, S., and Ahmad, S., 2012, Restudy of an Ediacaran medusoid Marsonia artiyansis Baghav et al., 2005, from the Jodhpur Sandstone, Jodhpur District, western Rajasthan: Journal of the Palaeontological Society of India, v. 57, p. 135-142.

Kumar, S., Misra, P.K., and Pandey, S.K., 2009, Ediacaran megaplant fossils with vaucheriacean affinity from the Jodhpur Sandstone, Marwar Supergroup, western Rajasthan: Current Science, v. 95, p. 701705.
Kumar, S., and Sharma, M., 2012, Vindhyan Basin, Son Valley Area, Central India, Lucknow, The Palaeontological Society of India, $145 \mathrm{p}$.

Kumar, S., Srivastava, D.K., and Ahmad, S., 2012, Five-armed body fossil from the Ediacaran Jodhpur Sandstone, Marwar Supergroup, western Rajasthan, India: a possible precursor of phylum Echinodermata: Current Science, v. 102, p. 2426.

Malone, S.J., Meert, J.G., Banerjee, D.M., Pandit, M.K., Tamrat, E., Kamenov, G.D., Pradhan, V.R., and Sohl, L.E., 2008, Paleomagnetism and detrital zircon geochronology of the upper Vindhyan sequence, Son Valley and Rajasthan, India: A ca. 1000 Ma closure age for the Purana basins? Precambrian Research, v. 164 , p. $137-159$.

McKenzie, N.R., Hughes, N.C., Myrow, P.M., Xiao, S., and Sharma, M., 2011, Correlation of Precambrian-Cambrian sedimentary successions across northern India and the utility of isotopic signatures of Himalayan lithotectonic zones: Earth and Planetary Science Letters, v. 312, p. 471-483.

Pandey, D.K., Uchman, A., Kumar, V., and Shekhawat, R.S., 2014, Cambrian trace fossils of the Cruziana ichnofacies from the Bikaner-Nagaur Basin, north western Indian Craton: Journal of Asian Earth Sciences, v. 81, p. 129-141.

Prasad, B., Asher, R., and Borgohai, B., 2010, Late Neoproterozoic (Ediacaran)-early Paleozoic (Cambrian) acritarchs from the Marwar Supergroup, Bikaner-Nagaur basin, Rajasthan: Journal of the Geological Society of India, v. 75, p. 415431.

Sharma, M., Pandey, S.K., and Kumar, S., 2014, International Field Workshop on the Marwar Supergroup, Rajasthan, India, Lucknow, The Society of Eearth Scientists, $80 \mathrm{p}$.

Srivastava, P., 2012, Problematic Worms and Priapulid-like Fossils from the Nagaur Group, the Marwar Supergroup, Western Rajasthan, India: Ichnos, v. 19, p. 156164.

Srivastava, P., 2014, Largest Ediacaran discs from the Jodhpur Sandstone, Marwar Supergroup, India: Their palaeobiological significance: Geoscience Frontiers, DOI:10.1016/j.gsf.2013.04.005.

Turner, C.C., Meert, J.G., Pandit, M.K., and Kamenov, G.D., 2014, A detrital zircon $\mathrm{U}-\mathrm{Pb}$ and $\mathrm{Hf}$ isotopic transect across the Son Valley sector of the Vindhyan Basin, India: Implications for basin evolution and paleogeography: Gondwana Research, DOI:10.1016/j.gr.2013.07.009. 